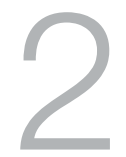

\title{
Great Expectations and the Twilight Zone: The Human Consequences of the Linking of Australia's International Student and Skilled Migration Programs and the Dismantling of that Scheme
}

\section{Sudrishti Reich}

\section{Introduction}

In the early to mid-2000s, an explicit government policy was developed to expand Australia's share of the lucrative and competitive international education market. A legitimate pathway was created from student status to permanent residence status. This scheme, intended to entice more foreign students and provide a source of locally trained young skilled migrants, was on one level hugely successful. It led to a massive and sustained increase in international student numbers. However, the policy was also, eventually, hugely damaging. It was damaging to the perceived effectiveness of the skilled migration program, and, ironically, to the international education industry it had been designed (in part) to assist. On a human level, when the 
scheme was dismantled, it was most damaging to thousands of former students who had invested, in good faith, in an Australian education and the prospect of becoming Australian permanent residents.

This chapter tracks and examines the sequence of immigration policy changes made in the student and skilled migration programs over the decade beginning in 2001, and explores their intended and unintended consequences. Most importantly, it focuses on and analyses the consequences for the thousands of former students whose lives were affected by the rapid dismantling of the government's policy of linking student visas with a migration outcome.

The first sequence of policy changes created a nexus between holding a student visa and becoming eligible for permanent skilled migration. Ultimately, the scheme provided for international students who had successfully completed their Australian qualifications in occupations considered to be in demand to satisfy the criteria for the grant of a permanent visa under the skilled migration program. As will be described, by mid-decade, the interrelationship between the student and skilled migration programs had begun to result in unintended and untenable consequences. The policies led to a boom in international student enrolments, particularly in the VET (Vocational Education and Training) sector, and a blow out in the number of applications for permanent skilled visas - which eventually exceeded the annual quota and created a pipeline of applications. Relying on the legislative pathway, increasing numbers of students applied to stay on permanently in Australia after completing their studies. Additionally, the policies resulted in an over-representation of certain occupations offered by skilled visa applicants, which, in the view of government, no longer reflected the skill needs of Australia nor served its economic interests. As a result of these cumulative consequences, a further series of policy changes were implemented that eventually de-linked the two components of the migration program.

This chapter describes how a reactive over-compensation to the outcomes of policy settings linking study in Australia with eligibility for permanent skilled migration left thousands of former international students languishing for years in a twilight zone of precarious temporary status. In doing so, it attempts to make visible this particular period in Australia's immigration history during which a sequence of policies were implemented in reaction to unfolding 
unintended consequences of previous policies, ostensibly in the national interest, yet with devastating consequences for a large group of former students. It analyses the effects of the policy reversal on these students/visa applicants and questions what lessons may be learned from this experience. These students were deliberately encouraged by government policy to choose Australia as their study destination by the offer of the possibility of transitioning to permanent residence. Having had their legitimate expectations raised, the laws were changed and visa processing priorities were adjusted, and their pathway to permanent residence was effectively blocked. This large cohort of disenfranchised applicants was left in an immigration no-man's land - not legitimate temporary workers, nor permanent residents, but instead permanent visa applicants. They have been left for years as temporary bridging visa ${ }^{1}$ holders, excluded from the rights and security of permanent residence status, despite having invested years of their lives in Australia. As permanent visa applicants holding bridging visas, they struggle to secure skilled employment and are rapidly de-skilling - forced into low-skilled, low-paid labour, and vulnerable to exploitation. In this process, their ability to contribute fully to the society they have chosen to join is being undermined. Yet, financially and socially, the price of going home without permanent residence is too high.

The picture is put together by examining the series of policy and legislative changes introduced over a decade; analysing the public policy statements (such as media releases and speeches) of government ministers throughout the period; referencing reports on the international education sector and media coverage of the policy shifts and their consequences; collating statistical data and policy documents from Australian Government websites; and drawing on the personal testimony of affected former students as published on a website established by and for the so-called G4/5rs.

1 A bridging visa is a temporary visa granted to a person who applies for a substantive visa. Its function is to give the bridging visa holder lawful status (permission to stay in Australia) during the processing of their substantive visa application. 


\section{The creation of a pathway from student to permanent resident status}

Three phases can be identified in Australia's relationship to international students. ${ }^{2}$

From the 1950s, under the Colombo Plan, ${ }^{3}$ it took the form of a foreign aid program that offered stipends to promising foreign students. These students, having gained their degrees and been exposed to Australian values, culture, and society, would take their newly acquired knowledge and skills back home and contribute to the growth and development of their country.

From the 1980s there was a fundamental shift 'from aid to trade' a market-based approach where Australia sold education to paying students. Having paid for their education, foreign students were generally not permitted under the migration laws to remain in Australia after completing their studies.

A third phase emerged at the start of the 2000s when the potential value to Australia of international students and their retention began to be realised. This phase was marked by international students being regarded as the solution to internal problems of increasing skills shortages and an ageing population. ${ }^{4}$ In a bid to boost Australia's share of the competitive international education industry, from 2001, gradual, cumulative changes to both the student visa program and the General Skilled Migration (GSM) program brought about an explicit link between studying in Australia and obtaining permanent residency. For the first time, eligible overseas students, upon successful completion of their studies, were able to apply onshore for permanent residency through the Skilled-Independent (and Skilled-Australiansponsored) visa categories of the GSM program. ${ }^{5}$ A direct pathway

2 See, for example, Eric Meadows, 'From Aid to Industry: A History of International Education in Australia' in Dorothy Davis and Bruce Mackintosh (eds), Making a Difference: Australian International Education (UNSW Press, 2011) 50.

3 The Colombo Plan for Cooperative Economic Development in South and Southeast Asia a scheme for bilateral aid for developing countries in South and Southeast Asia arising out of a meeting of Commonwealth Foreign Ministers held in Colombo, Ceylon, in January 1950.

4 See, for example, Elsa Koleth, 'Overseas Students: Immigration Policy Changes 1997May 2010' (Background Note, Parliamentary Library, 18 June 2010).

5 See Migration Regulations 1994 (Cth) sch 2 Visa subclass 880 Skilled-Independent Overseas Student and Visa subclass 881 Skilled-Australian-Sponsored Overseas Student. 
from holding a student visa to being granted a skilled permanent visa was established. In a win-win for Australia, overseas students became a source of young, acculturised, skilled workers who had paid for their own education.

In a series of further policy and legislative changes, this pathway was steadily widened. In April 2005, the Migration Occupations in Demand List (MODL) (an essential aspect of the skilled migration points system) was amended to include additional trade occupations, including cooks and hairdressers. The list was expanded further in both 2006 and 2007, incorporating more trade occupations. A trade qualification could be obtained within the two-year minimum period of study in Australia needed to qualify for a GSM visa. For applicants who were motivated by the prospect of applying for permanent residence, choosing a trade occupation (as opposed to a tertiary qualification) was a fast route.

At the same time, the skilled visa criteria were changed so that former students who applied within six months of being awarded their Australian qualification were exempt from the usual requirement of having some years of relevant skilled work experience. ${ }^{6}$ The combined effect of these legislative adjustments was to create a scheme whereby, by selecting a course of study that qualified an individual for one of the occupations on the MODL or that gained 60 points on the Skilled Occupations List (SOL), an international student was almost assured of becoming eligible for a permanent residence visa. ${ }^{7}$

The scheme effected a change to the landscape of the international student sector and the skilled migration program. From one perspective, the policy was extraordinarily successful - it led to a massive boost to international student enrolments in Australian educational institutions. There was a rapid rise in student numbers across all sectors, and a numbers explosion in the VET sector. ${ }^{8}$ In 2005 , (when the new trades were added to the MODL), there were 66,086 VET sector enrolments. Two years later in 2007, that number had

$6 \quad$ Ibid. See also Migration Regulations 1994 (Cth) sch 2 cl 136.21.

7 The arrangement is described further in Michael Knight, 'Strategic Review of the Student Visa Program 2011' (Report to the Australian Government, June 2011) 14. Available at: www.border.gov. au/ReportsandPublications/Documents/reviews-and-inquiries/2011-knight-review.pdf.

8 It is within this context of massive demand for VET courses that some of the damaging consequences of the scheme took shape. See Chapter 1, where Verma describes the consequential breakdown of the integrity of the international education industry. 
doubled. By 2009 it had almost doubled again. ${ }^{9}$ This phenomenon can be attributed directly to the expansion of the trade occupations included in the MODL list in 2005. By 2009, international education services had become Australia's largest service export industry, contributing $\$ 18.6$ billion to the economy. ${ }^{10}$

A feature of the boom was the changing profile of the source countries of the new students. The most dramatic change was the place taken by India. In just three years, between 2002 and 2005, India rose through the ranks of the top 10 source countries from ninth position to second, behind China, where it has remained since, despite the rapid drop off of new enrolments from India in 2009-10. ${ }^{11}$ In the five years from 2004-09 there was a six-fold increase in the number of Indian students enrolling (from 20,500 in 2004 to 120,000 in 2009). ${ }^{12}$

Importantly, there was also a change in the demographic of the students coming from India. The prospect of being able to convert an Australian qualification into permanent residency provided the incentive and the opportunity for a different class of young people to apply for international student visas. Indian students entering during the mid to late 2000s were no longer only the sons and daughters of India's elite, but now included the children of families from poorer socioeconomic groups, from rural and regional areas, and lower stratums of society. ${ }^{13}$ This new cohort has been described in a report of the Australia India Institute:

Many of the students were children of middle class, semi-rural parents who were not just leaving India for the first time, but had never left their home states ... There were other poignant aspects to their stories ... parents had borrowed money from private money-lenders at high rates of interest to fund their education. The expectation was that a good degree or diploma would lead to a work permit, facilitating

9 Figures from Australian Education International, International Student Data. Available at: internationaleducation.gov.au/research/International-Student-Data/Pages/default.aspx.

10 Australian Education International, 'Research Snapshot, Export Income to Australia from Education Services in 2009' (2010). Available at: www.aei.gov.au/research/Research-Snapshots/ Documents/Export\%20Income\%202009-10.pdf (site discontinued).

11 Figures from Australian Education International, above fn 9.

12 Ibid.

13 See Supriya Sing and Anuja Cabraal, 'Indian Student Migrants in Australia: Issues of Community Sustainability' (2010) 18 People and Place 25; Michiel Baas, 'Students of Migration: Indian Overseas Students and the Question of Permanent Residency' (2006) 14 People and Place 11. 
migration and citizenship. This was a reflection of the belief that Australia was a land of opportunity and merit, and that hard work, following an initial investment, would be rewarded there. ${ }^{14}$

The significance of this new type of overseas student was that, coming from lower socioeconomic backgrounds, there was much more at stake in achieving a migration outcome from the choice to study in Australia. This made them more vulnerable when the scheme was eventually dismantled.

In dependence on the scheme, increasing numbers of former students chose to convert their Australian qualifications into permanent residency by applying for skilled migration in Australia. This resulted in a significant change to the pattern of visa applications in the skilled migration program. The percentage of onshore applications increased rapidly and included greater numbers of former students. In fact, the numbers of applications being received by the end of 2009 exceeded the numbers of visas available for grant in that financial year. By 2009, approximately one third of students stayed on after completing their studies and applied for permanent residence. ${ }^{15}$ For the three to four years leading up to 2010, when the government reversed the policy, international students were the single largest contributor to Australia's net migration. ${ }^{16}$ There was an accompanying skewing of the skilled migration program with the pool of applicants dominated by a handful of occupations - for instance, a disproportionate number of cooks, hairdressers, IT professionals, and accountants. ${ }^{17}$ As critiqued in the Knight Review of the Student Visa Program: 'Instead of driving an increase in particular skills which Australia needed, the scheme ... ended up driving migration per se. ${ }^{\prime 18}$

14 John McCarthy et al., 'Perceptions Taskforce Beyond the Lost Decade' (Report of the Australia India Institute, 2012).

15 Dorothy Davis and Bruce Mackintosh (eds), Making a Difference: Australian International Education (UNSW Press, 2011) 403.

16 Chris Evans, Minister for Immigration and Citizenship, 'Changes to Australia's Skilled Migration Program' (Speech delivered at The Australian National University, Canberra, 8 February 2010).

17 Ibid.

18 Michael Knight, above fn 7, 15. 


\section{The government reaction: Reversal of policy and retraction of hope}

By the beginning of 2009, the rising flood of onshore skilled visa applications and the imbalance in the occupational skills offered by the applicants coincided with the arrival of the global financial crisis in Australia. The government responded by cutting the intake of skilled migrants. It also began a process of reforming the skilled migration program, which included prioritising visa applications from applicants with an Australian employer or state sponsor. By this means, the program was designed to be more demand driven as opposed to supply driven. It sought to address the problem of a backlog of skilled visa applications by cancelling 20,000 offshore GSM visa applications lodged before 1 September 2007. ${ }^{19}$

The government also moved quickly, through a sequence of legislative adjustments, to dismantle the scheme linking student status and permanent residence. In February 2010, the MODL was revoked with immediate effect. Since having an occupation on the MODL enhanced an applicant's ability to achieve a pass score on the points test, its revocation meant that many students would no longer be eligible for a permanent skilled visa. In May 2010, a new Skilled Occupation List (SOL) was announced to apply from July 2010. The new SOL halved the number of eligible occupations. Critically, the new SOL omitted the occupations of cook and hairdresser. From July 2011, a new points test commenced that gave greater weight to skilled work experience and English language ability. While existing students whose occupations were on the new SOL could still apply for permanent residence, the newly focused points test, particularly on skilled work experience, largely disenfranchised most former student applicants. The extent of the government's reaction to the perceived problem of the effects of the student to permanent resident scheme was demonstrated in the introduction of a bill to give the minister the power to cap the number of visas granted to applicants in any one occupation. ${ }^{20}$ If passed, this would have ceased certain already lodged visa applications from former

19 Chris Evans, Minister for Immigration and Citizenship, 'Migration Reforms to Deliver Australia's Skills Needs' (Media Release, 8 February 2010).

20 Ibid.; Migration Amendment (Visa Capping) Bill 2010. 
students onshore. In the event, however, parliament was prorogued for a general election before the bill could be voted on and it has not been re-presented.

The strategy that probably had the most damaging effect on existing visa applicants was the introduction, from 1 January 2009, of priority processing directions by the Minister for Immigration. These binding directions established the order in which applications in the skilled migration program should be processed. Under these directions, applications were no longer assessed in the order in which they were lodged. Rather, priority was given to applicants who suited Australia's perceived economic needs. The processing priorities since 1 July 2012 are, in descending order:

1. applications from people who are sponsored under the Regional Sponsored Migration Scheme (RSMS) program,

2. applications from people who are sponsored under the Employer Nomination Scheme (ENS) program,

3. applications from people who are nominated by a state or territory government agency [for an occupation specified on that agency's State Migration Plan],

4. applications from people who have nominated an occupation on the Skilled Occupation List (SOL) - Schedule 1 in effect from 1 July 2012,

5. all other applications. ${ }^{21}$

The effect of priority processing is that those without an employer or government sponsor are always being pushed to the back of the queue as new applications from sponsored applicants are processed first. In addition, applicants invited under the Skillselect scheme (introduced in mid-2012) are given priority within each of the priority categories.

It is important to remember that the pathway from student to permanent resident was legitimate. It was a deliberate government strategy to entice more international students to choose Australia.

21 Department of Immigration and Citizenship, Fact Sheet 24a: Priority Processing for Skilled Migration Visas (July 2012). Available at: www.immi.gov.au/media/fact-sheets/24apriority_ skilled.htm (site discontinued). 
This was reflected even in the government's official website for international students, Study in Australia. Under the heading, 'Employment: Your future. Your world', the site included the statement:

The Australian Government skilled migration program targets young people who have skills, an education and outstanding abilities that will contribute to the Australian economy. International students with Australian qualifications account for about half the people assessed under the skilled migrant program.

It went on to give a link to the Department of Immigration website. ${ }^{22}$

Yet in the minister's announcements of the various policy reversals, the government went so far as to seek to blame the overseas students for relying on the laws. In the words of Chris Evans, the Minister for Immigration at the time:

Students come here; they're coming to buy an education, not to buy a visa. ${ }^{23}$

The government recognises that the changes will affect some overseas students currently in Australia intending to apply for permanent residence ... The changes will in no way impact on international students coming to Australia to gain a legitimate qualification and then return home. ${ }^{24}$

The changes also remove incentives for international students to seek permanent residence through low quality education courses, a practice that damaged the integrity of both the migration program and the education industry. ${ }^{25}$

A statement included at the end of the Department of Immigration's information sheet on allocation of priority group five applications says: 'Many priority group 5 applicants still face a considerable wait until their application is allocated to a case officer for processing and

22 Web archive, Study in Australia Website. Available at: web.archive.org/web/20070620161512/ www.studyinaustralia.gov.au/Sia/en/AfterYourStudies/Employment.

23 Chris Evans, Minister for Immigration and Citizenship, 'New Skilled Occupation List to Meet Australia's Economic Needs' (Media Release, 17 May 2010).

24 Ibid.

25 Chris Evans, Minister for Immigration and Citizenship, 'Australia Continues to Welcome International Students' (Media Release, 8 September 2010). 
may wish to consider other options [emphasis added]. ${ }^{\prime 26}$ As there are no comparable permanent visa options that most in this group would be eligible for, the irresistible impression of this statement is that the government hopes that this embarrassing group of visa applicants will finally despair, give up, and leave Australia. However, another co-existent possibility may be that asserted by Sanmati Verma in Chapter 1, namely that, rather than intending to expel these former students, their existence in Australia created a new class of permanently provisional migrants, providing a useful pool of subordinated and flexible labour.

\section{Life in the twilight zone}

Priority processing has had a direct impact on the prospects of the vast majority of former student applicants who have applied in the independent stream and come within priority group five (PG5).

Technically, while the policy and legislative changes were not retrospective, in their effect they were. They altered the future prospects of thousands of students who were already studying in Australia. Many would realistically no longer be eligible for a GSM visa. Others faced an indefinite state of limbo, stuck in PG5, with any higher-priority applicant entering the system being processed ahead of them. These were students who had invested tens of thousands of dollars to study in Australia.

There were transitional provisions but these only offered students the possibility of obtaining an 18-month temporary work visa at the end of their studies. This would, if they were lucky, 'enable them to ... acquire work experience and seek sponsorship from an employer'. ${ }^{27}$ However, obtaining employer sponsorship was not a realistic possibility in most cases, as will be explained below.

\footnotetext{
26 Department of Immigration and Citizenship, Processing of Priority Group 5 General Skilled Migration Applications. Available at: www.immi.gov.au/skilled/general-skilled-migration/gsmpriority5-processing.htm (site discontinued).

27 Chris Evans, Minister for Immigration and Citizenship, ‘Options Remain for Overseas Students' (Media Release, 9 February 2010).
} 
As at 30 September 2013, there were still 11,380 PG5 people in Australia in the GSM pipeline. ${ }^{28}$ The total number of applications in the GSM pipeline as at 30 September 2013 was 67,219 persons. ${ }^{29}$ Meanwhile, the planning level (government quota) for the 2013-14 year for the GSM program was 73,840 — with new SkillSelect applicants being prioritised above all other categories.

As at 4 October 2013, applications from applicants in PG5 who had applied for the Skilled Independent visa (subclass 885) before 28 June 2010 were being allocated to a case officer for processing. For some of the provisional skilled visa classes, allocation had not commenced at all. ${ }^{30}$

This allocation date means that those applicants will have waited more than three years before their application is even allocated for processing. Given that one cannot apply until after completing one's Australian award, after a minimum of two years study, this means that these people have been living in Australia for a minimum of five years on temporary visas. Very many will have been living in Australia for even longer, depending on the number and type of courses they have undertaken - e.g. foundation studies and/or English language course (six months); bachelor degree course (three years); masters course (two years or more); $\mathrm{PhD}$ (three or four years or more). So, there will be some applicants in this group for whom Australia has effectively been home for the past 10 years, yet who are still existing in the limbo of temporary migration status - with all the detriment that that brings.

PG5 former students are languishing in an indeterminate pipeline of visa applicants. They remain as temporary residents, mostly not holding a substantive temporary visa but only a bridging visa. Their status, even as permanent visa applicants with a lawful right to remain in Australia, is precarious. ${ }^{31}$ They are prevented from settling and formally becoming part of the Australian community - perpetual

\footnotetext{
28 Figures supplied by email from the Department of Immigration and Border Protection to the author, 21 October 2013.

29 Ibid.

30 Department of Immigration and Citizenship, Allocation Dates for General Skilled Migration Applications. Available at: www.immi.gov.au/skilled/general-skilled-migration/ estimated-allocation-times.htm (site discontinued).

31 Note, for instance, the Migration Amendment (Visa Capping) Bill 2010 (Cth) (discussed above) sought to cancel a large number of GSM visa applications including from onshore applicants.
} 
temporary residents, even though Australia has been their home for many years. They work, pay taxes, have Australian friends and relatives, and, in some cases, Australian-born children. Yet their lives are forced to be lived in a holding pattern.

As bridging visa holders, they are not prohibited from working, however, their temporary and precarious immigration status makes them unattractive to employers, at least for employment in professional and other skilled occupations. This forces them into semiskilled or unskilled, low-paid work in which they are vulnerable to exploitation. ${ }^{32}$ The longer they are not engaged in using their qualifications and knowledge, the more they are deskilling and going backwards. This personal reality is described by a member of PG5:

In April 2008 I applied for the permanent residency (as a professional translator, supported by my law degree) with an expectation that I'd have a PR in 10 months (as my lawyer told me). Late of 2008, I was invited to take medical check and police record check by a case officer. After submitting all the required documents, I have been waiting for more than 2 years and ... no one has touched my application since then. Altogether I've been waiting for 3 years and 5 months (til now).

I'm not lucky as some of you guys who have found proper jobs. Except for 1 year working for the Uni while studying there, for 5 years I've worked for a supermarket. Not so bad job though but I worry that all knowledge and training I had achieved in studying are eventually dulling, day by day, in my manual work..$^{33}$

32 See, for example, Fair Work Ombudsman, 'Convenience Store Operators Fined \$150,000 for Underpaying International Students' (Media Release, 27 April 2011); Fair Work Ombudsman, 'Brisbane Café Back-Pays Students \$120,000 after Fair Work Ombudsman Investigation' (Media Release, 22 February 2010); Victorian TAFE International and United Voice, 'Taken to the Cleaners: Experiences of International Students Working in the Australian Retail Cleaning Industry' (November 2012). Available at: hdl.voced.edu.au/10707/232836.

33 Mr G Nuyen posted this statement on a website created by G5rs: G4 online. Available at: www.g4online.org/About-Australian-Skilled-Migration-Group-5, accessed 3 May 2013. (Note that this website has since become inaccessible and original information is no longer available at this site, but see related sites at www.facebook.com/pages/Australian-GSM-Group5-Applicants-Website/146625305386625 and www.facebook.com/pages/Australian-GeneralSkilled-Migration-Group-5previous-4/189378114433646.) 
Many have incurred massive debts back home (and/or family have sold property to pay for their education in Australia) so there is a strong imperative for them to earn enough not just to pay for their living expenses in Australia but also to remit repayments on the outstanding loans.

As bridging visa holders, they do not have freedom to come and go from Australia. To obtain a bridging visa B, which allows re-entry, one needs to demonstrate substantial reasons for needing to leave. It also costs money to apply.

Even now after 3 years of constant anticipation waiting to get what I (and all of us) rightfully deserve, my life is stagnant and all my goals and my personal growth are at a halt due to these policies. Employers continue to favour applicants with residency so nothing better works out, I cannot start my own business, cannot study and cannot go back to see my family without taking permission (which costs me again every time, and that too for no greater than 3 months under certain circumstances). ${ }^{34}$

There are other consequences of this group's temporary status: they are ineligible to sponsor their family members to join them in Australia. In some cases, partners are kept separated and children overseas remain separated from their parents in Australia. They are required to pay full fees for their children's schooling in Australia. They experience difficulty obtaining credit, including phone plans. As temporary or bridging visa holders, they are not eligible for social security support.

Former students affected by government policy reversals have limited options for normalising their status and their lives. Potential pathways are strewn with sometimes insurmountable hurdles. For instance, while they can try to find an Australian employer willing to sponsor them for an employer-sponsored permanent visa (RSMS or ENS), they are competing against other graduates, including Australian citizens and Australian permanent residents. The rules for eligibility for these visas require that the employer offers a three-year contract - which makes foreign graduates less attractive to employers. Visa eligibility criteria require a specified minimum salary to be offered, and require skilled work experience - which many overseas students will not have had

34 Ibid., Mr Tarun Kanda. 
the chance to obtain. Similar obstacles pertain when attempting to find an Australian employer willing to sponsor them for a temporary employer-sponsored visa (with a pathway after three years to being sponsored for permanent residence). Some former students may resort to so-called 'visa-churning' - the series of visa applications that former students might go through in order to stay on lawfully ${ }^{35}-$ while some may decide to risk staying in Australia unlawfully. Others may attempt legal action against the government to force the issue. ${ }^{36}$ And, of course, some may return home, having 'failed' in Australia. For many former students, this would be a very difficult choice. Many have lived, worked, and strived to make a life for themselves in Australia over many years, and returning home would require them to begin again from scratch. It can involve loss of face for themselves and their families, and an ongoing burden of debt as repaying educationrelated loans will be much harder, if not impossible.

I have spent 5 valuable years of my life in Australia and there has never been a day that I regret to date. However, if I am unable to remain in Australia permanently I will find it devastating for my son's development and for me and my husband's future as 5 years is a long time to be away from my country and to go back and rebuild our lives from scratch is beyond my frame of thinking let alone having to do same. $^{37}$

\section{Conclusion}

When Chris Evans introduced priority processing, the minister said that the old system was 'just like pulling a ticket number from the dispenser at the supermarket deli counter' and waiting to be served. ${ }^{38}$ He explained that it 'doesn't make sense' that Australia was 'taking hairdressers from overseas in front of doctors and nurses' ${ }^{39}$ As one commentator has pointed out, while this may be true from a national interest perspective, priority processing lacks procedural fairness

\footnotetext{
35 See Bob Birrell and Earnest Healy, 'Immigration Overshoot' (CPUR Research Report, Centre for Population and Urban Research, Monash University, 2012).

36 Bernard Lane, 'Irate Students May Not Go Home, Lawyer David Bitel Warns', The Australian, 24 September 2010. Available at: www.theaustralian.com.au/national-affairs/irate-students-maynot-go-home-lawyer-david-bitel-warns/story-fn59niix-1225928627942.

37 Nat, above fn 33.

38 Evans, above fn 16.

39 Ibid.
} 
and has had devastating impacts for individual applicants. ${ }^{40}$ Yet the personal detriment is also going to be felt at the national level. The inordinate delays in processing valid visa applications and granting visas has damaged these applicants' prospects for successful settlement and their ability to contribute to Australia to their full potential. The systematic delaying of settlement hindering the progression of people's lives and careers and the seemingly perpetual deferring of accepting this significant group of committed migrants formally into the community may be harmful not just to the individuals concerned but also to Australia's economic and social interests.

It is possible to make comparisons with temporary guest worker schemes, where 'the legal distinction between the status of citizen and of foreigner' will provide a clear criterion for conferring them with different political and social rights. But with the passage of time come 'inexorable pressures for settlement and community formation'. ${ }^{41}$ However, there is a distinction: temporary worker schemes are devised on the basis that the stay will be limited and/or revocable, while in the case of the former international students in Australia, they were given the expectation that their stay as a temporary student could potentially be converted into permanent residence. Instead, they find themselves resident in Australia without the formal recognition of resident status.

Some within this group of people living in the twilight zone have tried to organise, to agitate, to explore legal action, to try to get public attention to put pressure on the government. These are the selfnamed 'G5rs' ${ }^{42}$ They are asserting their right to a conclusion to this process, which will allow them access to the rights of membership of this community they have been a part of and been contributing to for many years. But overall, they are a relatively small and hidden group whose plight goes unnoticed.

40 Peter Mares, 'Internationalisation and a Big Australia: Debates on Migration, Education and Population' (presentation at the TAFE Directors Australia 2011 National Conference, Sydney, 6 September 2011). Available at: www.tda.edu.au/cb_pages/files/TDA \%20Internationalisation $\% 20$ and \%20big\%20Australia\%20Mares\%20060911\%20RPL.pdf.

41 Peter Mares, 'International Students and the Law of Unintended Consequences', Inside Story, 28 September 2001, quoting Stephen Castles and Mark J Miller, The Age of Migration: International Population Movements in the Modern World (Palgrave Macmillan, 4th edition, 2009). Available at: inside.org.au/international-students-and-the-law-of-unintended-consequences/.

42 Website cited at fn 33. 
It remains to be seen what policy-makers have learned from the experience of the G5rs. Certainly, students coming to Australia now are under no illusion that they will be eligible for permanent residence when they finish their course. The post-study work rights visa ${ }^{43}$ that commenced in March 2013 was introduced to help the education industry to recover from the effects of the de-coupling of the student visa and skilled migration programs. But what further problems will this visa create? What will become of these former students at the end of the work visa period? Are we creating more permanent temporary migrants, with no confirmed pathway to permanent resident status?

In a speech in late 2013, the Minister for Education in the Coalition Government, Christopher Pyne, made comments in relation to poststudy work rights: 'Our government will also give priority to reviewing post-study work rights to bring about clearer and more appropriate rules that maximise opportunities for graduates to convert worldleading qualifications to meaningful, needed careers. ${ }^{\prime 4}$

Further comments by the minister indicate that the government is considering re-establishing a pathway from student status to permanent residence:

This government will also seek to reverse the broad public perception which emerged under Labor that somehow foreign students must be prevented from getting a student visa on the basis they might one day aspire to live permanently in our great country.

... But other students, those that study here, gain an Australian qualification, make friends, bring their family out to visit, participate in, and are able to contribute to our society by filling an area of genuine workforce shortage. They are exactly the kind of people we want, and should want, at the front of our migration list - not at the end. ${ }^{45}$

This raises the immediate question of how the government intends to treat the former students languishing in PG5 - people who appear to fit that exact description.

43 The Temporary Graduate Visa, subclass 485, allows those graduating with a bachelor degree and above to stay and work in Australia for a period up to four years (depending on the level of qualification).

44 Pyne, Christopher, 'A New Architecture for International Education' (speech at the Australian International Education Conference, Canberra, 9 October 2013) 8.

45 Ibid., 9. 
In the context of swinging policies, each seemingly designed to ameliorate the unintended consequences of the previous, we can see the individuals detrimentally affected by the reversals as collateral damage. The rhetoric of blame shifting and the apparent reluctance with which the government has acted to rectify their position (by promptly processing their valid visa applications) indicates that while such individual harm was not intended, it is nevertheless an expedient consequence of the policies.

The final words go to one of the G5rs expressing the personal frustration felt by thousands of former international students whose legitimate expectations and need to formally participate in the Australian community were sacrificed in pursuit of a perceived national economic interest:

We now form a committed, educated, reforming, restructuring and tax paying part of the Australian Population and Australian Economy. Yet we are denied the basic rights every other resident and citizen has.

In conclusion to my story, I only plead to the DIAC [Department of Immigration and Citizenship] to have a fair go policy on us G5 applicants. We have been separated from our families, we have been diverted from our goals and our lives have been kept in Limbo for way too long now. Please consider the Values of Human Rights and Respect for Human Life which is the PROUD EMBLEM OF AUSTRALIA. ${ }^{46}$

\section{Bibliography}

\section{Articles, books, and reports}

Baas, Michiel, 'Students of Migration: Indian Overseas Students and the Question of Permanent Residency' (2006) 14 People and Place 8

Baas, Michiel, 'The Language of Migration: The Education Industry Versus the Migration Industry' (2007) 15 People and Place 49

Birrell, Bob and Ernest Healy, 'The February 2010 Reforms and the International Student Industry' (2010) 18 People and Place 65

46 Mr Tarun Kanda, above fn 33 and 34. 
Birrell, Bob and Earnest Healy, 'Immigration Overshoot' (CPUR Research Report, Centre for Population and Urban Research, Monash University, 2012)

Birrell, Bob and Bronwen Perry, 'Immigration Policy Change and the International Student Industry' (2009) 17 People and Place 64

Castles, Stephen and Mark J Miller, The Age of Migration: International Population Movements in the Modern World (Palgrave Macmillan, 4th edition, 2009)

Crock, Mary and Laurie Berg, Immigration Refugees and Forced Migration: Law, Policy and Practice in Australia (The Federation Press, 2011)

Davis, Dorothy and Bruce Mackintosh (eds), Making a Difference: Australian International Education (UNSW Press, 2011)

Hawthorne, Lesleyanne, 'Designer Immigrants? International Students and Two-Step Migration' in Darla K Deardorff et al. (eds), The SAGE Handbook of International Higher Education (SAGE Publications, 2012)

Knight, Michael, 'Strategic Review of the Student Visa Program 2011' (Report to the Australian Government, June 2011). Available at: www.border.gov.au/ReportsandPublications/Documents/reviewsand-inquiries/2011-knight-review.pdf

McCarthy, John et al., 'Perceptions Taskforce Beyond the Lost Decade' (Report of the Australia India Institute, 2012)

Meadows, Eric, 'From Aid to Industry: A History of International Education in Australia' in Dorothy Davis and Bruce Mackintosh (eds), Making a Difference: Australian International Education (UNSW Press, 2011)

Sing, Supriya and Anuja Cabraal, 'Indian Student Migrants in Australia: Issues of Community Sustainability' (2010) 18 People and Place 19

Ziguras, Christopher and Siew-Fang Law, 'Recruiting International Students as Skilled Migrants: The Global "Skills Race" as Viewed from Australia and Malaysia' (2006) 4 Globalisation, Societies and Education 59 


\section{Legislation}

Migration Amendment (Visa Capping) Bill 2010 (Cth)

Migration Regulations 1994 (Cth)

\section{Other}

Australian Bureau of Statistics, 'Australian Social Trends December 2011: International Students'. Available at: www.abs.gov.au/ AUSSTATS/abs@.nsf/allprimarymainfeatures/573AD76DFABE2D FCCA2579CE000BAD25?opendocument

Australian Education International, International Student Data. Available at: internationaleducation.gov.au/research/InternationalStudent-Data/Pages/default.aspx

Australian Education International, 'Research Snapshot, Export Income to Australia from Education Services in 2009' (2010) . Available at: www.aei.gov.au/research/Research-Snapshots/Documents/Export $\%$ 20Income\%202009-10.pdf (site discontinued)

Council of Australian Governments, 'International Students Strategy for Australia 2010-2014'. Available at: www.coag.gov.au/sites/default/ files/International \%20Students \%20Strategy \% 20-\%20PDF.pdf

Dai, Louis, David Elliot-Jones and Lachlan McLeod, Convenient Education (Chocolate Liberation Front, 2012)

Department of Immigration and Citizenship, Allocation Dates for General Skilled Migration Applications. Available at: www.immi. gov.au/skilled/general-skilled-migration/estimated-allocationtimes.htm (site discontinued)

Department of Immigration and Citizenship, Fact Sheet 24a: Priority Processing for Skilled Migration Visas (July 2012). Available at: www.immi.gov.au/media/fact-sheets/24apriority_skilled.htm (site discontinued)

Department of Immigration and Citizenship, Processing of Priority Group 5 General Skilled Migration Applications. Available at: www. immi.gov.au/skilled/general-skilled-migration/gsm-priority5processing.htm (site discontinued) 
Evans, Chris, Minister for Immigration and Citizenship, 'Changes to Australia's Skilled Migration Program' (Speech delivered at The Australian National University, Canberra, 8 February 2010)

Evans, Chris, Minister for Immigration and Citizenship, 'Migration Reforms to Deliver Australia's Skills Needs' (Media Release, 8 February 2010)

Evans, Chris, Minister for Immigration and Citizenship, 'Options Remain for Overseas Students' (Media Release, 9 February 2010)

Evans, Chris, Minister for Immigration and Citizenship, 'New Skilled Occupation List to Meet Australia's Economic Needs' (Media Release, 17 May 2010)

Evans, Chris, Minister for Immigration and Citizenship, 'Migration Options Remain for Chefs and Cooks' (Media Release, 18 May 2010)

Evans, Chris, Minister for Immigration and Citizenship, 'International Students Welcome in Australia' (Media Release, 10 June 2010)

Evans, Chris, Minister for Immigration and Citizenship, 'Australia Continues to Welcome International Students' (Media Release, 8 September 2010)

Fair Work Ombudsman, 'Brisbane Café Back-Pays Students $\$ 120,000$ after Fair Work Ombudsman Investigation' (Media Release, 22 February 2010)

Fair Work Ombudsman, 'Convenience Store Operators Fined $\$ 150,000$ for Underpaying International Students' (Media Release, 27 April 2011)

G4 online. Available at: www.g4online.org/About-Australian-SkilledMigration-Group-5, accessed 3 May 2013. (Note that this website has since become inaccessible and original information is no longer available at this site, but see related sites at www.facebook. com/pages/Australian-GSM-Group-5-Applicants-Website/ 146625305386625 and www.facebook.com/pages/AustralianGeneral-Skilled-Migration-Group-5previous-4/189378114433646)

Jensen, Erik, 'Some Private Colleges Are Visa Factories', The Sydney Morning Herald, 28 March 2007. Available at www.smh. com.au/news/national/some-private-colleges-are-visa-factoriesstudy/2007/03/27/1174761471743.html 
Koleth, Elsa, 'Overseas Students: Immigration Policy Changes 1997May 2010' (Background Note, Parliamentary Library, 18 June 2010)

Lane, Bernard, 'Irate Students May Not Go Home, Lawyer David Bitel Warns', The Australian, 24 September 2010. Available at: www. theaustralian.com.au/national-affairs/irate-students-may-not-gohome-lawyer-david-bitel-warns/story-fn59niix-1225928627942

Mares, Peter, 'International Students and the Law of Unintended Consequences', Inside Story, 28 September 2001. Available at: inside.org.au/international-students-and-the-law-of-unintendedconsequences/

Mares, Peter, 'Internationalisation and a Big Australia: Debates on Migration, Education and Population' (presentation at the TAFE Directors Australia 2011 National Conference, Sydney, 6 September 2011). Available at: www.tda.edu.au/cb_pages/files/ TDA $\%$ 20Internationalisation $\% 20$ and $\% 20$ big $\% 20$ Australia $\% 20$ Mares\%20060911\%20RPL.pdf

Mares, Peter, 'Temporary Migration Is a Permanent Thing', Inside Story, 20 March 2013. Available at: inside.org.au/temporarymigration-is-a-permanent-thing/

O'Malley, Nick, 'Visa Racket Leaves Foreign Students Exposed', The Sydney Morning Herald, 16 July 2009. Available at: www.smh. com.au/national/visa-racket-leaves-foreign-students-exposed20090715-dlja.html

Pyne, Christopher, 'A New Architecture for International Education' (Speech at the Australian International Education Conference, Canberra, 9 October 2013)

Trounson, Andrew, 'Humanity Denied in a Dash for Cash', The Australian, 5 May 2010. Available at: www.theaustralian.com. $\mathrm{au} /$ higher-education/humanity-denied-in-a-dash-for-cash/storye6frgcjx-1225862224911

Victorian TAFE International and United Voice, 'Taken to the Cleaners: Experiences of International Students Working in the Australian Retail Cleaning Industry' (November 2012). Available at: hdl. voced.edu.au/10707/232836

Web archive, Study in Australia Website. Available at: web.archive. org/web/20070620161512/www.studyinaustralia.gov.au/Sia/en/ AfterYourStudies/Employment 
This text is taken from Unintended Consequences: The impact of migration law and policy, edited by Marianne Dickie, Dorota Gozdecka and Sudrishti Reich, published 2016 by ANU Press, The Australian National University, Canberra, Australia.

The papers published in this book arose from an inaugural conference on migration law and policy at ANU College of Law, held in October 2013. They are reprinted here with minor amendments. 